\title{
Effects of milk fat, unhydrogenated and partially hydrogenated vegetable oils on fat metabolism of growing pigs I. Growth, feed utilization and carcass quality in pigs fed different fats and oils
}

\author{
Kaija SuOmi, Timo AlaviuhKola, Jarmo Valaja, VeikKo Kankare \\ and ASMO KEMPPINEN
}

\begin{abstract}
Suomi, K., Alaviuhikola, T., Valaja, J., Kankare, V. \& Kemprinen, A. 1993. Effects of milk fat, unhydrogenated and partially hydrogenated vegetable oils on fat metabolism of growing pigs. I. Growth, feed utilization and carcass quality in pigs fed different fats and oils. Agric. Sci. Finl. 2: 7-13. (Agric. Res. Centre of Finland, Inst. Anim. Prod., Swine Res. Sta. FIN-05840 Hyvinkää, Finland, Agric. Res. Centre of Finland, Food Res. Inst. FIN-31600 Jokioinen, Finland and Dept. Food Tech./Dairy Section, Viikki, FIN-00014 University of Helsinki, Finland.)
\end{abstract}

Two trials were conducted to study the effects of different dietary fats on the performance, carcass quality and meat quality of 75 crossbred growing pigs. The experimental diets contained $14.3 \%$ butter oil (BO), low erucic acid rapeseed oil (RO), sunflower oil (SO) or partially hydrogenated sunflower oil (HSO). The cream (CR) content of the diets was $29.4 \%$. The dietary fat addition comprised about $36 \%$ of the net energy content of the diets.

The fatty acid composition of the dietary fats had a clear influence on the fatty acid composition of the adipose tissue of the pigs. Vegetable oils ( $\mathrm{RO}$ and $\mathrm{SO}$ ) increased the unsaturated fatty acid content of the adipose tissue and decreased the firmness of the backfat compared to the effects by milk fat (BO, CR) $(\mathrm{p}<0.001)$. The correlation between linoleic acid content and firmness of back fat was significant $(r=-0.83)$ $(\mathrm{p}<0.001)$. The trans fatty acid $(\mathrm{C} 18: 1)$ found in HSO seems to be incorporated intact into the fatty tissue of the pig to a large extent and a significant difference was found in the contents of trans fatty acid C18:1 between the SO and HSO treatments $(p<0.001)$.

Significant differences were found in feed conversion efficiency, $\mathrm{kg} \mathrm{DM} / \mathrm{kg}$ gain, $(\mathrm{p}<0.05)$ and in the firmness of back fat $(\mathrm{p}<0.001)$ between the present vegetable oils (RO, SO, HSO) and the milk fat (BO, CR) dietary groups. Hydrogenated sunflower oil (HSO) increased the firmness of back fat compared to unhydrogenated sunflower oil (SO) $(\mathrm{p}<0.001)$, but in contrast, it significantly reduced daily gain and feed conversion efficiency $(\mathrm{p}<0.05)$. A vegetable oil addition of the level used in the present study is not recomended for pig diets because of the undesirable consistency of back fat.

Key words: pig, butter oil, rapeseed oil, sunflower oil, partially hydrogenated sunflower oil, cream, growth rate, feed conversion, meat quality

\section{Introduction}

Dietary fatty acids are required only in the form of linoleic and linolenic acid by growing pigs because they are not able to synthesize these fatty acids. The requirement of dietary linoleate for normal growth rate and feed efficiency is only $0.26 \%$ of ME according to CHRISTENSEN (1985) and it can be met 
without the addition of dietary fat on a barley based diet because of the $2 \%$ fat content of barley, $60 \%$ is in the form of linoleic acid (MADSEN 1983).

Approximately $4 \mathrm{~kg}$ fat (growth range from 20 to $90 \mathrm{~kg}$ ) is supplied by feed on a barley based diet (MADSEN et al. 1991). However, there is a remarkable synthesis of fat from other nutrients, mainly from carbohydrates, and therefore the carcass contains 3-4 times as much fat as that provided by conventional feed (MADSEN 1983). The efficiency of the utilization of carbohydrates for fat retention is lower than the utilization of fat energy because dietary fat is preferentially utilized for body fat in the pig (BERSCHAUER 1986). Therefore, dietary fatty acids are directly incorporated into the body fat, thus minimizing the heat losses associated with fat synthesis from acetyl CoA (BERSCHAUER 1986).

The firmness and cohesiveness of carcass fats in the pig are affected by the fatty acid composition of dietary fat. An excess of vegetable fats containing high amounts of unsaturated fatty acids in swine diets causes the body fat to be undesirably soft and decreases the keepability of fat (PALMQUIST 1988). The inclusion of high levels of animal fat (technical pig fat) into the diets also increased the content of unsaturated fatty acids, especially oleic acid and linoleic acid in the body fat (MADSEN 1983). Linoleic acid had a negative influence and stearic acid positively influenced the firmness of body fat (MADSEN et al. 1991).

The objectives of this part of the experiment were to study the effects of different dietary fats on the performance, carcass quality and fatty acid composition of the adipose tissue of growing pigs. The experiment was carried out in co-operation with the National Public Health Institute, the Agricultural Research Centre, the National Veterinary Institute, the University of Helsinki, the Department of Food Technology/Dairy Section, the Raisio Group and the Valio Finnish Co-operative Dairies' Association. The results concerning the effects of dietary fats on the lipid and cholesterol values of porcine serum and lipoprotein fractions and the evaluation of the suitability of pig as a model for human nutritional studies are presented in KEMPPINEN et al. 1993.

\section{Material and methods}

A total of 75 growing pigs were used in two experiments. In January 199050 pigs were assigned to five different treatments with ten pigs per treatment ( 5 females and 5 castrates). Eighty percent of the animals were crossbred (Yorkshire $x$ Landrace), the rest belonged to the Yorkshire breed. The second experiment was conducted in September 1990 with 25 growing pigs which were divided into five different treatments. Half of the animals were crossbred (Yorkshire and Landrace) and half were Yorkshires. The treatments were similar to the first trial and contained five pigs in each (three females and two castrates). The pigs were divided into the treatments according to litter origin, initial live weight and sex in both trials. One pig was placed in each pen.

The diet contained $14.3 \%(\mathrm{w} / \mathrm{w})$ added fat of butter oil (BO), low erucic acid rapeseed oil (RO), sunflower oil (SO) or partially hydrogenated sunflower oil (HSO). A $29.4 \%$ (w/w) addition of cream (CR) was added into the diet. The rest of the diet consisted of a low-fat, high-fiber basal feed (Table 1). Approximately $36 \%$ of the net energy content of the diet originated from added fats and oils.

The individually fed pigs received an equal amount of energy and protein daily in accordance with the Finnish energy and protein feeding recommendations (SALO et al.1982). The animals were housed on concrete flooring and fed twice daily. The pigs had free access to water. Daily rations of basal feed and fat were weighed into separate containers and given in two portions at 7.00 am and $14.30 \mathrm{pm}$. Feed consumption was registered daily and weight gain fortnightly. The average initial weight of the pigs was $25 \mathrm{~kg}$ and they were slaughtered after an experimental period of 88 days.

Blood samples were collected from the vena jugularis at baseline, after 42 days and finally after 88 days for the analysis of lipid values, cholesterol values and lipoprotein fractions in porcine serum. The sample was taken after about an 18-h fast. Fatty acids were analyzed from the basal feed, dietary fats and from the adipose tissue of the pig by the method of the AOAC (1984). The tocopherol content of the dietary fats was determined with a liquid 
Table 1. Dietary ingredients $(\%)$ and chemical composition of the basal diet.

\begin{tabular}{|c|c|}
\hline Ingredients: & $(\%)$ \\
\hline Barley & 36.5 \\
\hline Soy bean meal & 7.5 \\
\hline Fat-free milk powder & 38.5 \\
\hline Barley hulls & 13.0 \\
\hline Mineral and vitamin mixture ${ }^{2}$ & 4.5 \\
\hline \multicolumn{2}{|l|}{ Calculated chemical composition: } \\
\hline Feed unit $(F U / k g)^{1}$ & 0.95 \\
\hline Digestible crude protein, $\%$ & 19.8 \\
\hline Crude fibre, $\%$ & 5.1 \\
\hline Crude fat, \% & 0.99 \\
\hline Lysine, g/kg & 14.7 \\
\hline Calcium, g/kg & 14.7 \\
\hline Phosphorus, g/kg & 9.0 \\
\hline Selenium, mg/kg & 0.27 \\
\hline Vitamin E, mg/kg & 62.5 \\
\hline
\end{tabular}

1. $\mathrm{FU}=0.7 \mathrm{~kg}$ starch equivalent.

2. Composition of vitamin and mineral mixture:

$\mathrm{Ca}, \mathrm{g} / \mathrm{kg} \quad 200$

P, " 75

$\mathrm{NaCl}, " \quad 103$

Vitamin A, $1000 \mathrm{ky} / \mathrm{kg} \quad 350$

Vitamin D, " 57.2

Vitamin E, $\mathrm{mg} / \mathrm{kg} \quad 1200$

Se, $\quad \mathrm{mg} / \mathrm{kg} \quad 4$

chromatograph by the method of GERTZ and HERRMANN (1982).

The data were subjected to analysis of variance using the GLM procedure of SAS (1985). The model used to analyse the data was

$Y_{i j k l}=\mu+E_{i}+T_{j}+S_{k}+T_{i j}+e_{i j k l}$,

where $\mathrm{Y}_{\mathrm{ijkl}}=$ each individual observation, $\mu=$ overall mean, $\mathrm{T}_{\mathrm{j}}=$ effect of the treatment ( $\left.\mathrm{i}=1-5\right), \mathrm{S}_{\mathrm{k}}=$ effect of $\operatorname{sex}(j=1,2), E_{i}=$ effect of experiment $(\mathrm{k}=1,2)$ and $\mathrm{e}_{\mathrm{ijkl}}=$ residual term.

The orthogonal contrasts used to compare dietary fats were 1. vegetable fat (the sum of the effects of RO, SO and HSO) vs milk fat (the sum of the effects of BO and CR); 2. BO vs CR; 3. SO vs HSO; 4. RO vs SO.

\section{Results and discussion}

The fatty acid compositions of the basal feed and the dietary fats are presented in Table 2 . The basal feed contained predominantly linoleic acid (C18:2) $52.9 \%$, because of the high content of barley and soya bean meal in the feed. According to MADSEN et al. (1991) the linoleic acid contents of barley fat and soya bean meal fat are 44 and $51 \%$, respectively. Both RO and SO contained large amounts of unsaturated fatty acids and the most predominant fatty acid was oleic acid (C18:1) in RO (57.1\%) and linoleic acid in SO $(61.8 \%)$ which is in agreement with the results of MADSEN et al. (1990) and ØSTERBALLE et al. (1990). Partial hydrogenation of sunflower oil increased the content of trans fatty acids $(36.5 \%)$ compared to unhydrogenated sunflower oil. The saturated fatty acid content was clearly higher for milk fat (BO and CR) compared to the vegetable oils and milk fat is constituted mainly of myristic (C14:0), palmitic (C16:0), stearic (18:0) and oleic acid. Vegetable oils (RO, SO, HSO) clearly contained more $\alpha$-tocopherol compared to milk fat (BO, CR) (Table 2).

Dietary fat had a clear influence on the fatty acid composition of the adipose tissue (Table 3). The adipose tissue of the vegetable oil treatment groups (RO, SO, HSO) had a higher unsaturated/saturated fatty acids ratio (U/S) compared to the milk fat (BO and $(\mathrm{CR})$ treatment groups. The vegetable oils caused significantly softer adipose tissue compared to milk fat $(\mathrm{p}<0.001)$ (Table 4). In contrast to the other vegetable oils HSO had no negative effects on the firmness of the back fat. The reason for this was assumed to be the higher content of trans fatty acids in the back fat. According to MADSEN et al.(1977) the hydrogenation of fat changed the backfat from very soft ( 9.9 points) to very hard (14.9 points) (14\% hydrogenated fat/14\% unhydrogenated fat). Several reports confirm that an increased amount of vegetable fat in diet has negative effect on the firmness of adipose tissue (PALMQUIST 1988, SCHERF and BIEBER-WLASCHNY 1990, ØSTERBALLE et al. 1990, MADSEN et al. 1991).

Sunflower oil caused the highest content of linoleic acid in the adipose tissue and had the most negative effect on the firmness of the backfat (Table 3). According to BERSCHAUER (1984), the dietary intake of linoleic acid has the greatest influence on the firmness of adipose tissue. Our study 
Table 2. Fatty acid composition and $\alpha$-tocopherol content of basal feed and dietary fats ( $\% \mathrm{w} / \mathrm{w})$

$(\mathrm{BO}=$ Butter oil, $\mathrm{CR}=$ Cream, $\mathrm{RO}=$ Rapeseed oil, $\mathrm{SO}=$ Sunflower oil, HSO = Partially hydrogenated sunflower oil $)$.

\begin{tabular}{|c|c|c|c|c|c|c|}
\hline Feedstuff & Basal feed & BO & CR & RO & SO & HSO \\
\hline \multicolumn{7}{|l|}{ Fatty acid, $\% \mathrm{w} / \mathrm{w}$} \\
\hline $\mathrm{C} 4: 0$ & & 3.8 & 3.7 & & & \\
\hline C6:0 & & 2.5 & 2.7 & & & \\
\hline C8:0 & & 1.5 & 1.5 & & & \\
\hline C10:0 & & 3.1 & 3.3 & & & \\
\hline $\mathrm{C} 12: 0$ & & 3.2 & 3.5 & & & \\
\hline C14:0 & 0.2 & 10.7 & 11.8 & 0.1 & 0.1 & \\
\hline C16:0 & 19.1 & 25.3 & 30.0 & 3.5 & 6.2 & 7.1 \\
\hline C16:1 & 0.2 & 1.4 & 1.6 & 0.2 & 0.1 & \\
\hline C18:0 & 1.5 & 12.9 & 11.1 & 1.5 & 4.3 & 19.7 \\
\hline C18:1 cis & 16.4 & 23.6 & 21.0 & 57.1 & 24.9 & 34.2 \\
\hline C18:1 trans & & 2.6 & 1.6 & & & 36.0 \\
\hline $\mathrm{C} 18: 2 \mathrm{cis}$ & 52.9 & 2.1 & 1.8 & 23.0 & 61.8 & 1.0 \\
\hline $\mathrm{C} 18: 2$ trans & & 0.3 & 0.3 & & & 0.5 \\
\hline C18:3 & 7.0 & 0.6 & 0.4 & 11.0 & 1.5 & 0.1 \\
\hline Unsaturated fatty acids, \% & 77.4 & 32.8 & 29.0 & 94.2 & 88.3 & 72.1 \\
\hline Saturated fatty acids, $\%$ & 22.6 & 67.2 & 71.0 & 5.8 & 11.7 & 27.9 \\
\hline U/S-ratio ${ }^{1}$ & 3.4 & 0.5 & 0.4 & 16.2 & 7.5 & 2.6 \\
\hline$\alpha$-tocopherol mg/kg & 30.5 & 9.8 & 4.5 & 145.0 & 412.5 & 352.5 \\
\hline
\end{tabular}

${ }^{1}$ The ratio of unsaturated to saturated fatty acids

found a significant negative correlation between the linoleic acid content of adipose tissue and the firmness of the backfat $(\mathrm{r}=-0.83)(\mathrm{p}<0.001)$. According to MADSEN et al. (1991) the content of the sunflower seeds in the diet of growing pigs should not exceed $4 \%$ because the higher amount causes undesirably soft backfat and decreases the consistency and keepability of the meat.

The content of polyenoic fatty acids in the backfat should not exceed $12-15 \% \mathrm{w} / \mathrm{w}$ for the production of fermented sausages and bacon (HOUBEN and KROL 1984). In our study the polyenoic fatty acid content of adipose tissue exceeded the $15 \%$ level in the RO and SO pigs ( 25.4 and $45.0 \%$, respectively) and was under the $15 \%$ level in the other treatment groups (BO, HSO, CR) $(7.3,7.5$ and $6.9 \%$, respectively). Consequently, the quality of the fatty tissue of RO and SO pigs was unacceptable.

The pooled performance results of the two trials are presented in Table 4. No differences were found in the daily gain of the pigs fed vegetable oil or milk fat in our study (Table 4). MORTENSEN et al. (1983) found no differences between a dietary fat addition of animal fat or vegetable oil/fatty acid mixture in the performance of pigs. PALMQUIST (1988) found no difference in the daily gain and feed:gain ratio of the pigs fed tallow, lard or vegetable oil. The longchain saturated fatty acids (palmitic and stearic acid) present in milk and animal fat are less efficiently digested than the unsaturated fatty acids of vegetable oils (BERSCHAUER 1986). According to STAHLY (1984), the digestibility of fat from diets containing a ratio of unsaturated to saturated (U/S) fatty acids greater than 1.5 is relatively high, averaging $85-92 \%$, and the digestibility of fat in diets with a U/S ratio of less than 1.0-1.3 is substantially lower, ranging from $35 \%$ to $75 \%$. In our study, the U/S ratio was clearly lower than 1.5 for milk fat (BO and CR) and higher than 1.5 for vegetable oils (RO, SO and HSO) (Table 2), respectively.

There was a significant difference in feed:gain ratio between animals fed diets supplemented with animal or vegetable fats. This result supports the finding of PRABUCK (1977) and STAHLY (1984) 
Table 3. Fatty acid composition of adipose tissue of the pigs $(\% \mathrm{w} / \mathrm{w})$. LS-means of treatments are presented. (BO $=\mathrm{Butter}$ oil, $\mathrm{CR}=$ Cream, $\mathrm{RO}=$ Rapeseed oil, $\mathrm{SO}=$ Sunflower oil, $\mathrm{HSO}=$ Partially sunflower oil $)$

\begin{tabular}{llllllllll}
\hline Treatment & BO & CR & RO & SO & HSO & SEM $^{1}$ & & \multicolumn{2}{c}{ Statistical significance $^{2}$} \\
\end{tabular}

\section{Number of}

Animals 11

11

11

11

11

Fatty acid, \% w/w

\begin{tabular}{|c|c|c|c|c|c|c|c|c|c|c|}
\hline C10:0 & 0.20 & 0.20 & 0.06 & 0.06 & 0.05 & 0.009 & $* * *$ & NS & NS & NS \\
\hline $\mathrm{C} 12: 0$ & 0.46 & 0.48 & 0.09 & 0.08 & 0.11 & 0.012 & $* * *$ & NS & NS & NS \\
\hline $\mathrm{C} 14: 0$ & 4.46 & 4.85 & 1.02 & 0.97 & 1.25 & 0.083 & $* * *$ & $* *$ & $*$ & NS \\
\hline $\mathrm{C} 16: 0$ & 24.98 & 26.12 & 12.38 & 13.22 & 14.33 & 0.266 & $* * *$ & $* *$ & * & NS \\
\hline C16:1 & 3.67 & 4.07 & 1.01 & 0.91 & 1.81 & 0.084 & $* * *$ & $* *$ & $* * *$ & NS \\
\hline C18:0 & 11.45 & 10.90 & 6.32 & 7.31 & 9.80 & 0.282 & $* * *$ & NS & $* * *$ & $*$ \\
\hline C18:1 cis & 41.99 & 41.21 & 48.51 & 28.65 & 42.12 & 0.452 & $* * *$ & NS & $* * *$ & $* * *$ \\
\hline C18:1 trans & 1.05 & 0.96 & 0.83 & 0.76 & 18.89 & 0.249 & $* * *$ & NS & $* * *$ & NS \\
\hline C18:2 cis & 5.97 & 5.65 & 18.71 & 43.33 & 5.40 & 0.388 & $* * *$ & NS & $* * *$ & $* * *$ \\
\hline C18:2 trans & 0.31 & 0.31 & 0.01 & 0.00 & 1.23 & 0.012 & $* * *$ & NS & $* * *$ & NS \\
\hline $\mathrm{C} 18: 3$ & 0.93 & 0.92 & 6.93 & 1.44 & 0.82 & 0.054 & $* * *$ & NS & $* * *$ & *** \\
\hline $\begin{array}{l}\text { Unsaturated } \\
\text { fatty acids, \% } \\
\text { Saturated }\end{array}$ & 55.89 & 55.05 & 79.05 & 77.49 & 73.12 & 0.454 & $* * *$ & NS & $* * *$ & * \\
\hline fatty acids, \% & 44.11 & 44.95 & 20.95 & 22.51 & 26.88 & 0.453 & $* * *$ & NS & $* * *$ & * \\
\hline U/S-ratio ${ }^{3}$ & 1.3 & 1.2 & 3.7 & 3.5 & 2.7 & & & & & \\
\hline
\end{tabular}

1. $\mathrm{SEM}=$ standard error of means

2. Significance: NS(nonsignificant), ${ }^{*}(\mathrm{P}<0.05),{ }^{* *}(\mathrm{P}<0.01),{ }^{* * *}(\mathrm{P}<0.001)$

$\mathrm{C} 1=$ Vegetable fat (RO, SO, HSO) vs. Milk fat $(\mathrm{BO}, \mathrm{CR}), \mathrm{C} 2=$ Butter oil vs. Cream, C3 = Hydrogenated sunflower oil vs. Unhydrogenated sunflower oil, $\mathrm{C} 4=$ Rapeseed oil vs. Sunflower oil

3. The ratio of unsaturated to saturated fatty acids

Table 4. Performance and carcass quality of the pigs. LS-means of the treatments are presented. $(\mathrm{BO}=\mathrm{butter}$ oil, $\mathrm{CR}=\mathrm{cream}$, $\mathrm{RO}=$ rapeseed oil, $\mathrm{SO}=$ sunflower oil, $\mathrm{HSO}=$ partially hydrogenated sunflower oil $)$.

\begin{tabular}{|c|c|c|c|c|c|c|c|c|c|c|}
\hline \multirow[t]{2}{*}{ Treatment } & \multirow[t]{2}{*}{$\mathrm{BO}$} & \multirow[t]{2}{*}{ CR } & \multirow[t]{2}{*}{ RO } & \multirow[t]{2}{*}{ SO } & \multirow[t]{2}{*}{ HSO } & \multirow[t]{2}{*}{ SEM $^{1}$} & \multicolumn{4}{|c|}{ Statistical significance ${ }^{2}$} \\
\hline & & & & & & & $\mathrm{Cl}$ & $\mathrm{C} 2$ & $\mathrm{C} 3$ & $\mathrm{C} 4$ \\
\hline Number of Animals & 15 & 15 & 14 & 15 & 15 & & & & & \\
\hline Daily gain, g/day & 754 & 796 & 795 & 818 & 776 & 13.82 & NS & $*$ & $*$ & NS \\
\hline Feed conversion & & & & & & & & & & \\
\hline rate, $\mathrm{kg} \mathrm{DM} / \mathrm{kg}$ gain & 2.16 & 2.12 & 2.05 & 1.99 & 2.12 & 0.04 & $*$ & NS & $*$ & NS \\
\hline Loss at slaughter, $\%$ & 24.0 & 22.9 & 24.0 & 23.2 & 23.8 & 0.34 & NS & $*$ & NS & NS \\
\hline Sidefat, mm & 15.3 & 14.8 & 12.7 & 16.1 & 14.0 & 0.91 & NS & NS & NS & $*$ \\
\hline Firmness of fat & & & & & & & & & & \\
\hline $\begin{array}{l}\text { score } 9-15 \\
\text { Meat in carcass, \% }\end{array}$ & $\begin{array}{l}14.6 \\
55.9\end{array}$ & $\begin{array}{l}14.8 \\
55.6\end{array}$ & $\begin{array}{l}10.3 \\
55.4\end{array}$ & $\begin{array}{l}10.1 \\
54.9\end{array}$ & $\begin{array}{l}14.7 \\
55.6\end{array}$ & $\begin{array}{l}0.12 \\
0.77\end{array}$ & NS & $\begin{array}{l}\text { NS } \\
\text { NS }\end{array}$ & NS & $\begin{array}{l}\text { NS } \\
\text { NS }\end{array}$ \\
\hline
\end{tabular}

\footnotetext{
1. $\mathrm{SEM}=$ standard error of means
}

2. Significance: NS (nonsignificant), ${ }^{*}(\mathrm{P}<0.05),{ }^{* *}(\mathrm{P}<0.01),{ }^{* * *}(\mathrm{P}<0.001)$

$\mathrm{Cl}$ = Vegetable fat $(\mathrm{RO}, \mathrm{SO}, \mathrm{HSO})$ vs. Milk fat $(\mathrm{BO}, \mathrm{CR}), \mathrm{C} 2=$ Butter oil vs. Cream, C3 = Hydrogenated sunflower oil vs. unhydrogenated sunflower oil, $\mathrm{C} 4=$ Rapeseed oil vs. sunflower oil 
(ref. Berschauer 1986), who reported the ME- content of vegetable oils to be $31.4-35.8 \mathrm{kj} / \mathrm{g}$ and 27.6 - $35.6 \mathrm{kj} / \mathrm{g}$ in animal fats.

In the comparison between the individual fats, pigs grew significantly better with CR than with BO $(\mathrm{p}<0.05)$ and with SO better than with HSO $(\mathrm{p}<0.05)$. HSO significantly impaired feed conversion efficiency $(\mathrm{p}<0.05)$. Hydrogenation impaired the digestibility of animal fat from 97 to $88 \%$ (MADSEN et al. 1977). The same effect was also noticed with fish oil according to OPSTVEDT (1984).

It can be concluded that the availability of energy from HSO compared to SO was lower. The pigs in HSO group grew slower and had lower carcass fat contents than the pigs in SO group.

In conclusion, our results showed that the dietary fatty acids were directly incorporated into the adipose tissue. Both vegetable oils and milk fat seemed to be suitable for swine diets. However, vegetable oils increased the unsaturated fatty acid content of the fat and decreased the firmness of the backfat. Because of that, the vegetable oil addition of $14.3 \%$ $(w / w)$ of the diet is not recommended for swine diets. It was also found that hydrogenation decreased the net energy value of sunflower oil.

\section{References}

AOAC 1984. Official methods of analysis. Ed. Association of Official Analytical Chemists, Virginia.

BersChauer, F. 1984. Influence of fatty acid intake on the fatty acid composition of the backfat in pigs. In: Wood, J.D. (ed.). Fat quality in lean pigs. Brussels. Commision of the European Communities. p. 74-82.

- 1986. Fats in diets for growing pigs. Pig News and Information. 7, 2: 153-158.

Christensen, K. 1985. Bestemmelse af linolsyrebehov til slaktesvin. 577. Beretn. fra Statens Husdyrbrugsforsøg, København. 158 p.

Gertz, C. \& Herrmann, K. 1982. Zur Analytik der Tocopherole und Tocotrienole in Lebensmitteln. Z. Lebensm. Unters. Forsch. 174: 390-394.

Houben, J.H. \& KROL, B. 1984. Pig fats and the manufacture and storage of meat products. In: Wood, J.D. (ed.). Fat quality in lean pigs. Brussels. Commision of the European Communities. p.15-26.

KempPinen, A., Jauhiainen, M., Kankare, V., Valaja, J., Alaviuhrol.a. T., Aro, A. \& Antil.A, P. 1993. Effects of milk fat, unhydrogenated and partially hydrogenated vegetable oils on fat metabolism of growing pigs. II. Changes in serum lipoprotein and lipid levels. Agric. Sci. Finl. 2: 15-23.

Madsen, A., Christensen, K., Christensen, K. D. \& MorTENSEN, H. P. 1977. Dietary fats for growing pigs. International Symposium on Animal Fats in Pig Feeding. Dubrovnik. 86-100.

- 1983. Feeding effects on fat deposition and fat quality. CEC Workshop on Fat Quality in Lean Pigs. p. 1-6.

-, Mortensen, H.P. \& Jakobsen, K. 1991. Dietary Influence on Carcass Fat in Pigs. Proc. 42nd Annual Meeting of EAAP, Berlin.

-, Østerballe, R., Mortensen H.P., Bejerholm, C. \& BarTON.P. 1990. Råvarekvalitet. Fodrets indflydelse på råvarekvaliteten hos slagtesvin 1. 673. Beretn. fra Statens Husdyrbrugsforsøg, Foulum. 73 p.

Mortensen, H. P., Madsen, A., Bejerholm, C. \& Barton, P.
1983. Fedt og fedtsyrer til slagtesvin. 540. Beretn. fra Statens Husdyrbrugsforsøg, København. 48 p.

Opstvedt, J. 1984. Fish fats. In. Wiseman, J. (ed.). Fats in Animal Nutrition. Butterworths, Boston p. 53-82.

PalmQuist, D. L. 1988. The Feeding Value of Fats. In: Ørskov, E.R. (ed.). Feed Science. World Animal Science. B4 p. 293-311.

Prabuck, A. L. 1977. Fats and oils as feedstuffs. In: Kling, M. \& Wöhlbier, W. (eds.). Handelsfuttermittel 1, Stuttgart, Ulmer p. 565-579. (Ref. Berschauer, F. 1986).

SAlo, M.-L., TuORI, M. \& Kinskinen, T. 1982. Rehutaulukot ja ruokintanormit. 70 p. Helsinki.

SAS 1985. SAS User's Guide: Statistics. 5 th Ed. SAS Institute Inc., Cary, NC, USA. 956 p.

SCHERF, H. \& BIEBER-WLASCHNY, M. 1990. How nutrition influences fat quality. Pig International. 2: 14, 16, 18, 20.

Stahly, T. S. 1984. Use of fat in diets for growing pigs. In: Wiseman, J. (ed.). Fats in Animal Nutrition. Butterworths, Boston. p. 313-331.

Østerballe, R., Madsen, A., Mortensen, H. P. Bejerholm, C. \& BARTON, P. 1990. Råvarekvalitet. Fodrets indflydelse på råvarekvaliteten hos slagtesvin 2. 685. Beretn. fra Statens Husdyrbrugsforsøg, Foulum. 58 p.

\section{Manuscript received June 1992}

Kaija Suomi

Timo Alaviuhkola

Jarmo Valaja

Agricultural Research Centre of Finland

Swine Research Station

Tervamäentie 179

FIN-05840 Hyvinkää, Finland

Veikko Kankare

Agricultural Research Centre of Finland

Food Research Institute

FIN-31600 Jokioinen, Finland 


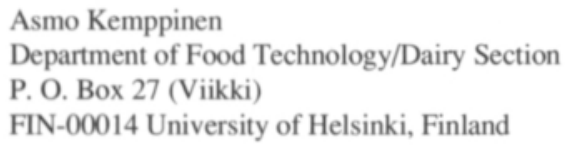

\title{
SELOSTUS
}

\section{Ravintorasvat lihasikojen ruokinnassa}

\author{
Kaija Suomi, Timo Alaviuhkola, Jarmo Valaja, VeikKo KanKare \\ ja ASMO KEMPPINEN
}

Maatalouden tutkimuskeskus ja Helsingin yliopisto

Tutkimus kuului yhteistutkimukseen "Ravintorasvojen vaikutus sydän - ja verisuonitautien riskitekijöihin". Tämän osatutkimuksen tarkoituksena oli selvittää erilaisten ravintorasvojen; voi -, rypsi -, auringonkukka - ja kovetetun auringonkukkaöljyn sekä kerman vaikutus sikojen kasvuun, rehun hyväksikäyttöön, teuraslaatuun ja lihan laatuun. Veren kolesterolitutkimuksen tulokset julkaistaan toisaalla tässä lehdessä (Kemprinen et al. 1993).

Voi-, rypsi-, auringonkukka- ja kovetetun auringonkukkaöljyn osuus rehusta oli $14,3 \%$. Kerman määrä rehuseoksessa oli $29,4 \%$. Perusrehu, johon rasvat lisättiin, koostui vähärasvaisista ja kuitupitoisista raaka-aineista. Rasvan lisäystaso vastasi noin $36 \%$ rehun nettoenergiasta. Siat ruokittiin kaksi kertaa päivässä rajoitetuin normein (1,2-2,8 ry/el/pv).

Ravintorasvojen rasvahappokoostumuksella oli selvä vai- kutus sikojen silavan rasvahappokoostumukseen. Kasviöljyjen monityydyttymättömät rasvahapot, erityisesti linolihappo, varastoituivat suoraan silavaan ja heikensivät merkitsevästi silavan kiinteyttä. Kovetettu auringonkukkaöljy nosti transrasvahappojen pitoisuutta silavassa. Silavan linolihappopitoisuuden ja kiinteyden välillä oli voimakas negatiivinen korrelaatio $(\mathrm{p}<0.001)$.

Kasviöljyjen ja maitorasvan välillä ei ollut muita eroja sikojen tuotantotuloksissa kuin maitorasvalla saatu hivenen heikompi rehun hyväksikäyttö. Öljyn kovettaminen heikensi sen energia-arvoa.

Tulokset osoittivat, että kasviöljy ja voirasva soveltuvat lihasikojen rehuksi. Kokeessa käytetty kasviöljyn lisäystaso oli kuitenkin liian korkea, koska se heikensi selvästi silavan kiinteyttä. 